\title{
Infectious Maize rayado fino virus from Cloned cDNA
}

\author{
Michael C. Edwards, John J. Weiland, Jane Todd, and Lucy R. Stewart
}

First and second authors: United States Department of Agriculture-Agricultural Research Service (USDA-ARS) Cereal Crops Research Unit, Fargo, ND 58102-2765; third and fourth authors: USDA-ARS Corn, Soybean, and Wheat Quality Research Unit, Wooster, OH 44691. Accepted for publication 22 January 2015.

\begin{abstract}
Edwards, M. C., Weiland, J. J., Todd, J., and Stewart, L. R. 2015. Infectious Maize rayado fino virus from cloned cDNA. Phytopathology 105:833-839.

A full-length cDNA clone was produced from a U.S. isolate of Maize rayado fino virus (MRFV), the type member of the genus Marafivirus within the family Tymoviridae. Infectivity of transcripts derived from cDNA clones was demonstrated by infection of maize plants and protoplasts, as well as by transmission via the known leafhopper vectors Dalbulus maidis and Graminella nigrifrons that transmit the virus in a persistent-propagative manner. Infection of maize plants through vascular puncture inoculation of seed with transcript RNA resulted in

the induction of fine stipple stripe symptoms typical of those produced by wild-type MRFV and a frequency of infection comparable with that of the wild type. Northern and Western blotting confirmed the production of MRFV-specific RNAs and proteins in infected plants and protoplasts. An unanticipated increase in subgenomic RNA synthesis over levels in infected plants was observed in protoplasts infected with either wild-type or cloned virus. A conserved cleavage site motif previously demonstrated to function in both Oat blue dwarf virus capsid protein and tymoviral nonstructural protein processing was identified near the amino terminus of the MRFV replicase polyprotein, suggesting that cleavage at this site also may occur.
\end{abstract}

Maize rayado fino virus (MRFV) is the type member of the genus Marafivirus within the family Tymoviridae (15). As such, it has a positive-strand RNA genome of approximately $6.3 \mathrm{~kb}$ that is encapsidated in isometric particles and encodes a large polyprotein with domains characteristic of this family. In contrast to the related tymoviruses that produce a single coat protein $(\mathrm{CP})$, marafivirus particles are composed of two coat proteins that differ in an aminoterminal extension on one of the two forms $(11,18)$. The virus induces a fine chlorotic stipple-striping in infected leaves of maize (Zea mays), with virus particles detectable in phloem sieve elements and phloem parenchyma as well as epidermal cells (24). MRFV and other marafiviruses that infect plants in the family Poaceae are transmitted in a persistent propagative manner by their leafhopper vectors $(25,37)$, with which they have species-specific virus-vector associations (15). MRFV is naturally transmitted by Dalbulus maidis, the corn leafhopper, although it has been experimentally transmitted by D. elimatus, Stirellus bicolor, Baldulus tripsaci, and Graminella nigrifrons (36). Together with the corn stunt spiroplasma and maize bushy stunt mycoplasma, MRFV is a component of the maize stunt disease complex $(4,16)$. Epidemics of MRFV alone and in conjunction with other pathogens can seriously impact yield if infection of the crop occurs early in the growing season $(14,21,44)$.

The development of cDNA clones from which infectious RNA can be produced has become integral to research on positive-strand RNA viruses of plants and insects. Marafiviruses infect both plants and insects and therefore comprise a unique system for investigations comparing infection strategies across biological kingdoms. Although vector specificity $(2,20,29,36)$ and a lack of mechanical transmissibility impose a significant constraint on investigations in this group of viruses, this impediment has been partially overcome in maize and small grains by the development of

Corresponding author: M. C. Edwards;

E-mail address: michael.edwards@ars.usda.gov

http://dx.doi.org/10.1094/PHYTO-09-14-0250-R

This article is in the public domain and not copyrightable. It may be freely reprinted with customary crediting of the source. The American Phytopathological Society, 2015 the vascular puncture inoculation (VPI) technique, which abrogates the need for the insect vector in virus inoculation $(30,32,43)$.

Techniques for producing and inoculating recombinant viral genomes would open new avenues for investigation of the marafiviruses and further our general knowledge of virus-vector interactions. We recently produced an infectious clone of Oat blue $d$ warf virus (OBDV) and verified its transmission by the six-spotted leafhopper Macrosteles quadrilineatus, its natural vector (8). In the present study, a cDNA clone of a U.S. isolate of MRFV was produced (pMRFV-US) that induces stunting and chlorotic stipplestriping in maize plants and the accumulation of viral products characteristic of native MRFV infection. Furthermore, the cloned virus was transmissible by both the corn leafhopper (D. maidis) and the black-faced leafhopper ( $G$. nigrifrons). This constitutes the first report of a full-length MRFV cDNA clone from which infectious RNA can be generated, providing the foundation for future discoveries regarding marafivirus host specificity, vector relations, and genome expression and replication strategies.

\section{MATERIALS AND METHODS}

Virus strains and cloning materials. MRFV-US (3) (American Type Culture Collection [ATCC] isolate PV-438) and anti-MRFV antiserum (ATCC PVAS-250) were obtained from the ATCC (Manassas, VA) and transferred via modified VPI (43) to hybrid Z. mays 'Silver Queen' (Morgan County Seeds, Barnett, MO). Infected plants were harvested and the leaves freeze dried, pulverized, and stored at $-80^{\circ} \mathrm{C}$ as a long-term stock of virus inoculum. Plasmid pGEM-T Easy (Promega, Inc., Middleton, WI) served as cloning vector for all constructs, and cloned DNA was maintained and amplified in Escherichia coli Zymo-5 $\alpha$ cells (Zymo Research, Irvine, CA). Unless otherwise indicated, all cloning procedures followed standard methods outlined by Sambrook and Russell (38). All DNA oligonucleotide primer synthesis and DNA sequence generation was provided by Eurofins Genomics (Huntsville, AL).

RNA reverse transcription, cloning, and synthetic transcript production. Preparation of MRFV-US virus and viral RNA and determination of the MRFV-US genome 3 '-end sequence was 
previously described (9). Primer MRFdT60rev (5'AACTAGT (T) ${ }_{60}$ GGCCCAC $3^{\prime}$ ), complementary to the polyA-tail and anchor nucleotides within the $3^{\prime}$-noncoding region of the genome and encoding an SpeI restriction enzyme site for clone linearization, was produced to prime reverse transcription. Genome-length firststrand cDNA was generated using $15 \mathrm{U}$ of Thermoscript (Life Technologies, Inc., Grand Island, NY) reverse transcriptase and $100 \mathrm{ng}$ of MRFV-US RNA primed with 10 pmol MRFdT60rev in a reaction containing $50 \mathrm{mM}$ Tris-acetate $(\mathrm{pH} 8.4), 75 \mathrm{mM}$ potassium acetate, $4 \mathrm{mM}$ magnesium acetate, $5 \mathrm{mM}$ dithiothreitol, $0.1 \mathrm{mM}$ each dNTP, and $40 \mathrm{U}$ of Rnasin ribonuclease inhibitor (Promega, Inc., Madison, WI) in a reaction volume of $20 \mu \mathrm{l}$. Following incubation at $50^{\circ} \mathrm{C}$ for $60 \mathrm{~min}$, the cDNA was diluted $1 / 10$ and used as template to produce a $3^{\prime}$ half-genome length amplicon by polymerase chain reaction (PCR) using primers MRF2981fwd (5'CAGGACAAGTGGCGCTTTGGCAC3') and MRFdT60rev and high-fidelity Platinum Taq DNA polymerase (Life Technologies, Inc.). Amplification reactions $(30 \mu \mathrm{l})$ included $60 \mathrm{mM}$ Tris-sulfate ( $\mathrm{pH} 8.9$ ), $18 \mathrm{mM}$ ammonium sulfate, $2 \mathrm{mM}$ magnesium sulfate, $30 \mathrm{ng}$ of each forward and reverse primer, $0.1 \mathrm{mM}$ each dNTP, $1 \mu \mathrm{l}$ of diluted cDNA, and 1 unit of Platinum Taq DNA polymerase and were incubated, per cycle, at $94^{\circ} \mathrm{C}$ for $1 \mathrm{~min}, 50^{\circ} \mathrm{C}$ for $1 \mathrm{~min}$, and $72^{\circ} \mathrm{C}$ for 3 min over a total of 40 cycles.

A SMART-RACE CDNA end characterization kit was obtained from Clontech, Inc. (Mountain View, CA) and used to reverse transcribe, clone, and characterize the $5^{\prime}$ end of the MRFV-US genome using kit components and protocols in conjunction with MRFV-specific primer MRF229rev (5'CTTTGGGATGGACC AAGGGTA3'). Based on sequence analysis of cloned amplicons
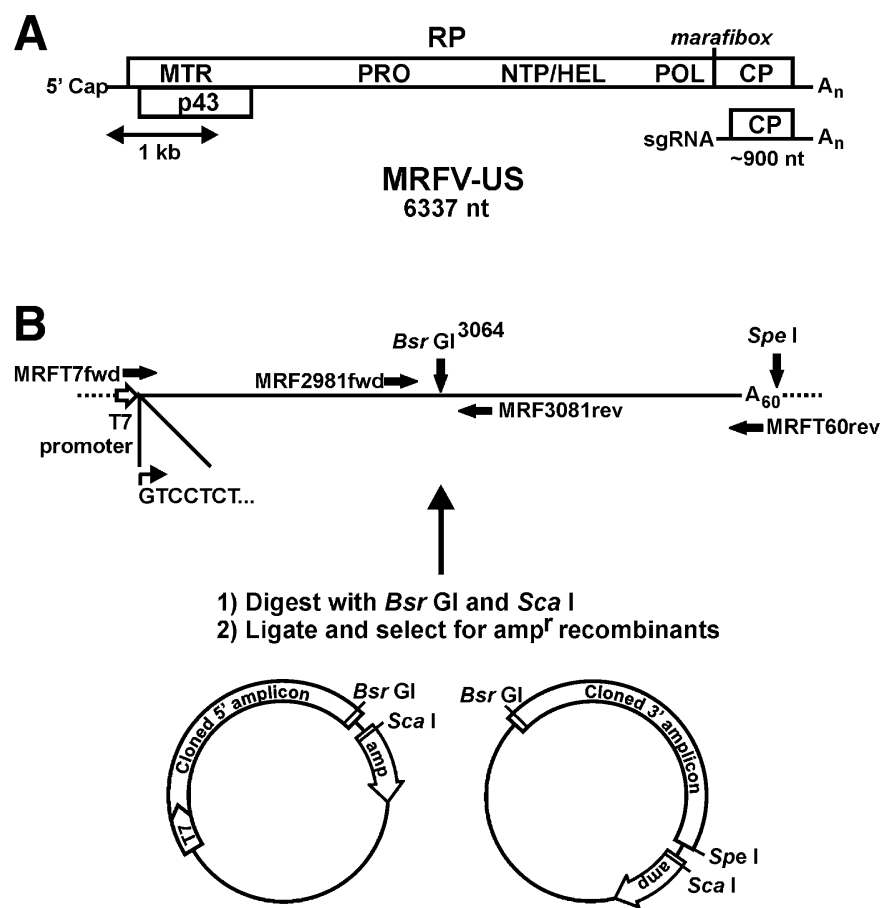

Fig. 1. A, Genome map of Maize rayado fino virus (MRFV) indicating the polyA tail $\left(A_{n}\right)$, the $5^{\prime}$ cap structure $(C A P)$, and its general expression strategy. A single subgenomic RNA (sgRNA) proposed to serve as mRNA for production of viral coat proteins (CP) is shown. The replicase polyprotein (RP) open reading frame (ORF) fused in frame to the ORF encoding the CP possesses domains for protease (PRO), NTPase/helicase (NTP/HEL), and RNAdependent RNA polymerase (POL) activities. The p43 ORF overlaps and is out-of-frame with the RP ORF. B, General strategy of the cloning of MRFV-US. The T7 RNA polymerase promoter is indicated by the shaded arrow. Approximate primer positions and their polarity are indicated (dark arrows). Cloned half-genome-size amplicons were fused at the unique BsrGI restriction enzyme site. Transcripts initiate at the first $\mathrm{G}$ residue of the genome sequence (bent arrow) and terminate at the SpeI site. following 5'-RACE, a primer for $5^{\prime}$-end amplification was designed and designated MRFT7 (5'TAATACGACTCACTA $T_{A G_{1}}$ TCCTCTGCCCCCTTCTTGC $^{\prime}{ }^{\prime}$ ), with the italicized bases representing the T7 RNA polymerase promoter and the remaining bases representing the first 20 nucleotides (nt) of the MRFV-US genome (transcription by RNA polymerase initiates at $G_{1}$ ). An amplicon representing the $5^{\prime}$ half of the MRFV genome was produced using primer MRFT7 in combination with MRF3081rev (5'GAGCAAAATCACGAACTGAATGGCG3') using reaction conditions described above for $3^{\prime}$-amplicon generation. Both $5^{\prime}$-half and $3^{\prime}$-half genome amplicons were ligated into pGEM-T Easy and recovered clones were partially sequenced to verify clone integrity. The 5' - and 3'-half genome-length constructs were digested at a unique $B s r G I$ restriction site present in an overlapping region of the amplicons (Fig. 1) and at the $S c a I$ site in the $\beta$-lactamase gene. Fusion of gel-purified half plasmids by ligation and subsequent transformation of $E$. coli permitted strong selection for recombinants on ampicillin-containing medium. All final clones were sequenced in both directions (Eurofins Genomics). Capped transcripts of clones were generated by methods routinely used in our laboratory (8) after linearization of clone plasmid DNA with restriction enzyme SpeI.

Plant and protoplast inoculation. VPI of maize seed as originally described by Louie (30) and modified by Weiland and Edwards (43) was used to test infectivity of clone-derived transcripts. Maize seed was soaked for $2 \mathrm{~h}$ at $30^{\circ} \mathrm{C}$ in distilled water containing $1 \times$ Fungigone (Bio-World, Inc., Dublin, OH). Softened seed were tamped dry, arranged on a glass plate with the embryo side up, and inoculated with either MRFV RNA or clone transcript RNA at $0.5 \mu \mathrm{g} / \mathrm{seed}$ (average $1 \mu \mathrm{l}$ volume/seed), as reported in Weiland and Edwards (43). Parallel inoculations were performed with sap expressed from infected plants in $10 \mathrm{mM}$ potassium phosphate buffer $(\mathrm{pH}$ 7.0) or partially purified virus. Inoculated seed were arranged on wetted filter paper in glass petri dishes and incubated in the dark for $24 \mathrm{~h}$ at $30^{\circ} \mathrm{C}$. Seeds (5/pot) were planted in MetroMix 902 soil mix (Sun Gro Horticulture, Agawam, MA) and plants maintained in a growth chamber at $27^{\circ} \mathrm{C}$ with a $16-\mathrm{h}$ day length. One clone inducing symptoms characteristic of MRFVinfected maize was designated pMRFV-US and was the subject of the remaining investigations in this work.

Mesophyll protoplasts were prepared from barley and oat leaves as previously described (42). Maize seedlings reared in a growth chamber $\left(22^{\circ} \mathrm{C}\right.$ per 14 -h day length) were harvested as the first true leaf was emerging (approximately 6 days postplanting) and protoplasts were prepared from leaf tissue essentially as described in Weiland and Edwards (42), except that the enzyme digestion mixture contained $1.5 \%$ Onozuka Cellulase RS, $0.3 \%$ Macerozyme R10 (PhytoTechnology Laboratories, Shawnee Mission, KS), and $0.01 \%$ bovine serum albumin dissolved in $0.55 \mathrm{M}$ mannitol ( $\mathrm{pH} 5.6$ ) buffered with MES-KOH. Approximately 1 to $2 \mathrm{~g}$ (fresh weight) of leaves were digested in $30 \mathrm{ml}$ of enzyme digestion mixture within 3 to $4 \mathrm{~h}$ at $30^{\circ} \mathrm{C}$. Protoplast enrichment, electroporation conditions, and subsequent incubation were performed by a modification of the procedure by Matsuda and Dreher (33) as described by Edwards and Weiland (10), using approximately $1 \mu \mathrm{g}$ of RNA applied to $5 \times 10^{5}$ protoplasts/inoculation.

Virus transmission by leafhoppers. Three species of leafhoppers were used to determine whether cloned MRFV-US was leafhopper transmissible. Transmission of wild-type MRFV-US by $D$. maidis was considered the positive control, while attempts to transmit either wild-type or cloned MRFV-US by M. quadrilineatus (a nonvector species) served as a negative control. Transmissibility by $G$. nigrifrons, an experimental vector of both viruses, was also tested. D. maidis (originally collected in Kings County, CA), G. nigrifrons, and M. quadrilineatus (both originally collected in Wooster, $\mathrm{OH}$ ), were reared on oat (Avena sativa 'Armor'; W. I. Miller \& Sons, Farmdale, OH) and sweet corn plants (Z. mays 'Early Sunglow'; Schlessman Seeds, Milan, $\mathrm{OH}$ ) sown in composted, $\mathrm{pH}-$ balanced, autoclaved soil. 
Virus transmission was tested in a manner similar to that used previously (44). First instar nymphs were allowed to feed on VPIinoculated, symptomatic sweet corn plants for a 7- to 14-day acquisition access period, followed by weekly transmission to healthy Early Sunglow seedlings with one to three leaves. Thus, leafhoppers were moved to new target plants each week and allowed a 7-day inoculation access period on each set of target plants. Transmission of cloned MRFV-US relative to the wild-type check was tested in three separate experiments with $D$. maidis and in four experiments with $G$. nigrifrons. A minimum of two to four weekly transfers were done within each experiment. All insects and plants for acquisition and transmission were caged and confined in an environmental chamber (Conviron, Winnipeg, Manitoba, Canada) with a light and temperature regimen of $15 \mathrm{~h}$ of light and $9 \mathrm{~h}$ of darkness at $25^{\circ} \mathrm{C}$. Plants were fumigated with an aerosol insecticide (1100 Pyrethrum TR; Whitmire Micro-Gen Research Laboratories, Inc., St. Louis) after each transfer and held 3 weeks for symptom development. Successful transmission, reported as total number of infected plants, was determined by development of symptoms typical for MRFV infection. Within the present study, all symptomatic plants tested positive by enzyme-linked immunosorbent assay (ELISA). Additionally, a bioassay utilizing symptomatic plants as source plants for subsequent leafhopper transmission confirmed infection.

Detection of viral products. Protoplasts were harvested at 24 or $40 \mathrm{~h}$ postinoculation and processed for the analysis of viral RNA and protein, as previously described $(10,42)$. Total protein (for Western blots) and glyoxalated nucleic acids (for Northern blots) from $10^{5}$ protoplasts were separated using denaturing gel electrophoresis on $12 \%$ polyacrylamide gels containing $0.1 \%$ sodium dodecyl sulfate (SDS) and 1\% agarose gels, respectively, and blotted to transfer membranes. Western blots were first incubated with anti-MRFV rabbit polyclonal antiserum and, subsequently, with goat antirabbit immunoglobulin $\mathrm{G}$ conjugated to alkaline phosphatase (Sigma-Aldrich, St. Louis). A doublestranded DNA digoxigenin (DIG)-labeled amplicon representing nucleotides 5,887 to 6,231 of MRFV-US was heat denatured and used to probe Northern blots in DIG Easy Hyb (Roche Diagnostics, Indianapolis, IN). Chemiluminescent detection was used to visualize protein and RNA on Western (Lumiphos WB; Thermo Scientific, Rockford IL) and Northern (CDP Star; Roche Diagnostics) blots, respectively. Blot images were recorded on a Luminary/FX imaging system (Fotodyne, Inc., Hartland, WI).

Leaf samples from maize plants were harvested 2 weeks postinoculation (by VPI) and the presence of virus was confirmed by ELISA, as previously described $(6,9)$. An absorbance reading of greater than $5 \times$ that of the uninfected check was considered positive. For the analysis of viral RNA from whole-plant samples, plant tissue was harvested at 28 days postinoculation (dpi) and homogenized in extraction buffer $(1 \%$ SDS, bentonite at $3 \mathrm{mg} / \mathrm{ml}$, $10 \mathrm{mM}$ Tris- $\mathrm{HCl}$ [pH 8.0], $1 \mathrm{mM}$ disodium EDTA, and $0.1 \mathrm{M}$ sodium chloride) using buffer at $10 \mathrm{ml} / \mathrm{g}$ of fresh weight tissue. The homogenate was extracted twice with buffered phenol-chloroformisoamyl alcohol (25:24:1) and nucleic acids were recovered from the aqueous fraction by ethanol-ammonium acetate precipitation. Nucleic acids were resuspended in sterile, distilled water for use in Northern blot analysis.

Genome sequencing and analysis. The genome sequence of clone pMRFV-US was deposited in GenBank under accession number KM523134. Nucleic acid and protein sequence alignments were performed with Clustal W (27) and gaps were introduced manually to highlight features relevant to the investigation. GenBank accession numbers for viruses discussed in the text and figures are Bermuda grass etched-line virus (AY040531), Blackberry virus $S$ (FJ915122), Citrus sudden death-associated virus (NC_006950), Grapevine asteroid mosaic-associated virus (AJ249357), Grapevine rupestris vein feathering virus (AY706994), Grapevine Syrah virus-1 (NC_012484), MRFV Costa Rican isolate
(MRFV-CR, NC_002786), OBDV (NC_001793), OBDV clone 2r (OBDV-2r, GU396990), Olive latent virus-3 (NC_013920), Poinsettia mosaic virus (NC_002164), Switchgrass mosaic virus (SwMV, NC_015522), and Turnip yellow mosaic virus (TYMV, $\mathrm{X} 16378$ ).

\section{RESULTS}

Clone construction and sequence analysis. Experiments with native OBDV genomic RNA and clone OBDV-2r (8) together with validation of the existence of a poly-A tail at the 3 ' terminus of the MRFV genome (9) suggested that a poly-A tail of approximately $60 \mathrm{nt}$ would be necessary and sufficient for infectivity of a synthetic MRFV genome. Consequently, $60 \mathrm{nt}$ of A residue was incorporated into the clone via the $3^{\prime}$-terminal primer designed for cDNA synthesis and subsequent amplification by PCR (Fig. 1). Use of $5^{\prime}$-RACE indicated the $5^{\prime}$-end untranslated leader of the MRFV-US genome to be GGUCCUCUGCCCCCUUCUUGCGCC CGAUCGCCGCAAGUCGCAUUCUGCACCAGCUCUCGCUCG UCCAGAAACAGAUCAAUCUUUCGGCCUCUUUUCUUGCAC UCUUCUUCGUUGCACCUCUCUAGAUG..., where the first $\mathrm{G}$ nucleotide (italicized) is proposed to be an artifact of the reverse transcription of the cap structure (19) and the underlined AUG represents the initiator-methionine codon for the replicase polyprotein (RP). A hybrid primer for clone construction was based on the $5^{\prime}$-RACE results, fusing the T7 RNA polymerase promoter sequence to $5^{\prime}$-end MRFV genome sequences in a manner to ensure correct $5^{\prime}$-end generation. Half-genome length cDNA clones were generated that allowed fusion of $5^{\prime}$-half and $3^{\prime}$-half clones at a unique $B s r$ GI site. Resulting genome-length clones possess an SpeI site immediately $3^{\prime}$ of the polyA tail, digestion at which produces linear templates for transcription (Fig. 1). Initial infectivity assays with seven putative full-length clones showed that four were infectious. One of the clones, indistinguishable from the wild type, was designated pMRFV-US and used for the in-depth analysis described herein to establish a reference clone for future research.

Sequence comparison indicated that MRFV-US is closely related to the previously reported MRFV-CR isolate, with $92 \%$ nucleotide sequence identity (pairwise BLAST, full sequences, for both). Moreover, amino acid sequence identities of $97 \%$ in the large encoded polyprotein (not including the major $\mathrm{CP}$ ), $82 \%$ in the overlapping encoded $\mathrm{p} 43$, and $97 \%$ in the major $\mathrm{CP}$ were present between the two viruses. Not including the cap structure and polyA tail, the genome of MRFV-US is 6,337 nt long and possesses a nucleotide composition of $24 \% \mathrm{G}, 15 \% \mathrm{~A}, 23 \% \mathrm{U}$, and $38 \% \mathrm{C}$, characteristic for members of the family Tymoviridae.

Infectivity in plants and protoplasts. Capped transcripts synthesized from clone pMRFV-US were infectious to maize, with inoculation efficiencies of 38 to $96 \%$ in three independent inoculations (Table 1). Infected plants developed fine stipplestriping symptoms characteristic of MRFV and indistinguishable in appearance and development from those induced by parallel inoculations with MRFV RNA (Fig. 2A), with sap of MRFVinfected plants, or with partially purified MRFV. All plants that exhibited MRFV symptoms tested positive by ELISA using antiMRFV antiserum. Occasional plants that could not be rated for symptoms but tested positive by ELISA were extremely stunted, atypical plants that resulted from embryo damage during inoculation. Viral genomic RNA (gRNA) and subgenomic RNA (sgRNA) were readily detectable in infected maize at $28 \mathrm{dpi}$, as were both major and minor CPs (Fig. 2B), with all products migrating at their predicted positions relative to size standards in gel electrophoresis.

Inoculation of maize protoplasts with capped transcripts of MRFV-US also yielded readily detectable viral products after 24 or $40 \mathrm{~h}$ of incubation (Fig. 3A). Western blotting with anti-MRFV antiserum revealed the presence of two predominant proteins 
consistent in size with the major and minor CPs, and which accumulated to levels comparable with those of wild-type MRFV CPs (Fig. 3A). Both gRNA and sgRNA also accumulated to levels comparable with those of the wild type (Fig. 3A). Strikingly, MRFV sgRNA accumulated to much higher levels in infected protoplasts than in whole plants, as shown by the gRNA/sgRNA ratios (Fig. $3 \mathrm{~A})$. The infection of oat and barley protoplasts in parallel experiments yielded similar results (not shown).

Leafhopper transmission. To further test the authenticity of the cloned virus, we wished to determine whether it was transmissible by leafhoppers. Transmission assays with two known MRFV vectors were conducted. Assays with D. maidis and $G$. nigrifrons demonstrated that the cloned virus was, indeed, transmissible by both vector species, with $9 \%$ transmission by D. maidis (19 infected plants per 205 total plants) and $25 \%$ transmission by $G$. nigrifrons (51 infected plants per 206 total plants). Wild-type virus was transmitted by $D$. maidis at a rate of $11 \%$ (64 infected plants per 595 total plants) and by G. nigrifrons at $8 \%$ (18 infected plants per 227 total plants). When transmission of the cloned virus by the nonvector species $M$. quadrilineatus was tested as a check, no transmission occurred ( 0 of 50 ). In addition, transmission by both vector species was successful for both wildtype and cloned viruses at the earliest tested interval of 7 days after first exposure to infected plants.

\section{DISCUSSION}

This is the first report of an infectious clone of MRFV and only the second infectious clone of a marafivirus after OBDV (8). The cloned virus induced symptoms typical of MRFV and was transmissible by two of its known insect vectors, further confirming its authenticity. Virus transmission assays with $D$. maidis and $G$. nigrifrons demonstrated that wild-type MRFV-US and cloned MRFV-US were transmissible at comparable levels by both leafhopper species. The range of transmissibility observed ( 8 to 25\%) is not unusual for leafhopper-borne viruses, which are typically quite variable in their transmissibility (20). Furthermore, transmission of both wild-type and cloned viruses by both vector species at the earliest tested interval of 7 days after first exposure to infected plants indicates that the latent periods for each virus are similar.

Consistent with previous reports characterizing MRFV $(13,18,28,32)$ and similar to OBDV $(8,10)$, two forms of capsid protein were present in infected plants and protoplasts. Investigations on both OBDV (11) and MRFV (18) indicated that the two proteins are carboxy-coterminal, with the larger protein possessing an amino-terminal extension of the smaller. Hammond and Ramirez (18) and Hammond and Hammond (17) proposed that the two proteins may result from initiation at two independent initiation codons, although proteolytic processing to release the polymerase while forming a larger capsid protein, as proposed for OBDV (10), cannot be ruled out.

The detection of a discrete MRFV sgRNA ostensibly generated for the translation of $\mathrm{CP}$, consistent with the expression strategy characteristic of the family Tymoviridae, is presented here for the first time. Whereas a single abundant sgRNA accumulated in protoplasts (Fig. 3), the CP sgRNA previously was either not detectable (12) or presumed to be represented among numerous smaller RNAs detected in plant extracts (31). The sgRNA is of low abundance relative to gRNA in viral RNA prepared from purified MRFV (Figs. 2 and 3), as is the case with the sgRNA of OBDV (8); no apparent difference was observed in the gRNA/sgRNA ratio of OBDV between infected oat plants and protoplasts $(8,10)$. The fact that differential sgRNA accumulation is not observed in plant versus protoplast infections with OBDV warrants further investigation and may reflect nucleotide sequence or spacing differences between MRFV and OBDV at the proposed start site of sgRNA transcription (Fig. 3). The greater amount of MRFV
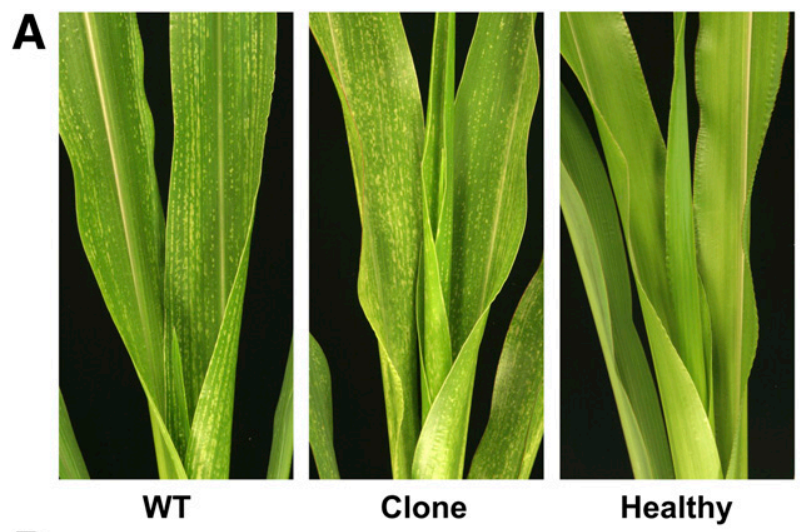

B

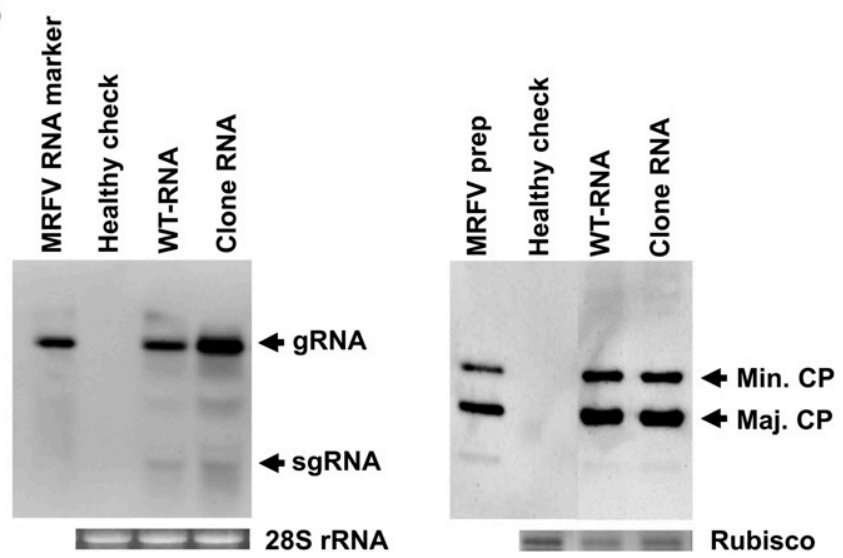

Fig. 2. A, Symptoms induced by wild-type (left) and cloned (middle) Maize rayado fino virus U.S. isolate (MRFV-US) at 28 days postinoculation as compared with the healthy check (right). B, Accumulation of viral products in plants infected with wild-type or cloned MRFV-US. Northern blot (left panel) showing the accumulation of viral genomic RNA (gRNA) and subgenomic RNA (sgRNA), as indicated by Northern blotting and hybridization with a probe to the $3^{\prime}$ end of the genome. Ethidium-bromide-stained $28 \mathrm{~S}$ rRNA prior to gel blotting was used as a well-loading control. Western blot (right panel) showing the accumulation of the major (Maj. CP) and minor (Min. CP) viral capsid proteins. A partially purified preparation of MRFV was used as a size standard. Coomassie-blue-stained ribulose bisphosphate carboxylase (large subunit; Rubisco) was used as a gel loading standard.

TABLE 1. Infectivity of wild type Maize rayado fino virus (MRFV) RNA and MRFV transcripts derived from cDNA clone pMRFV-US following vascular puncture inoculation of maize seed

\begin{tabular}{|c|c|c|c|c|c|}
\hline Rep & Inoculum & Plants emerged & Symptomatic plants & ELISA positive $^{a}$ & Positive $(\%)^{\mathrm{b}}$ \\
\hline \multirow[t]{2}{*}{1} & MRFV RNA & 28 & 18 & 18 & $64 \%$ \\
\hline & Clone RNA & 28 & 26 & 27 & $96 \%$ \\
\hline \multirow[t]{2}{*}{2} & MRFV RNA & 23 & 17 & 17 & $74 \%$ \\
\hline & Clone RNA & 26 & 15 & 17 & $65 \%$ \\
\hline \multirow[t]{2}{*}{3} & MRFV RNA & 26 & 14 & 16 & $62 \%$ \\
\hline & Clone RNA & 24 & 9 & 9 & $38 \%$ \\
\hline
\end{tabular}

a Enzyme-linked immunosorbent assay (ELISA).

b Percentage of emerged plants testing positive by ELISA. 
sgRNA produced in mesophyll protoplasts versus plants is intriguing and may reflect differing physiology between host cell types. MRFV is largely restricted to phloem and parenchyma cells in whole-plant infections $(24,26)$ and is not considered to invade mesophyll cells, which predominate in protoplast preparations. The ability of protoplasts from several species within the family Poaceae to support replication of MRFV, as demonstrated here, will be valuable in future comparative genomic studies between MRFV and other members of the family Tymoviridae.

Analysis of the sequence of clone pMRFV-US indicated commonality in both physical and coding features with the previously reported sequence of MRFV-CR (18). Both possess the characteristic high cytidine content of genomes of the family Tymoviridae (7), the putative promoter sequence block directing sgRNA synthesis (marafibox) $(10,22)$, an encoded large polyprotein (RP) that fuses replication-associated domains with the CP gene, and an open reading frame (ORF) encoding a 43-kDa protein (p43) of unknown function that overlaps out of frame the ORF encoding the RP (Fig. 1) (15). Notable exceptions to these similarities include the length of pMRFV-US at 6,337 nt, in contrast to the 6,305 nt reported for the Costa Rican isolate; a combined nucleotide insertion and deletion contributing to a short region of frameshifted sequence within the polyprotein ORF; and the previously confirmed presence of a polyA tail (9). The length difference is primarily attributed to the longer $5^{\prime}$-end untranslated leader in MRFV-US. Our 5' RACE results (not shown) clearly demonstrated the presence of $28 \mathrm{nt}$ at the $5^{\prime}$ terminus that are not present in the reported sequence of MRFV-CR (18), resulting in a 124-nt 5' terminal untranslated region versus $96 \mathrm{nt}$ for MRFV-CR and $108 \mathrm{nt}$ for SwMV (1), a close relative of MRFV. With the exception of an additional $\mathrm{G}$ residue reported to initiate the genome sequence of SwMV (GGUCC...) (1), both pMRFV-US and SwMV genomes begin with the same $11 \mathrm{nt}$ and have $89.3 \%$ identity between their 5 '-terminal $28 \mathrm{nt}$. Thus, it appears that the published sequence of MRFV-CR may be truncated, although the possibility that 5'-terminal sequence disparities reflect variation between geographical isolates cannot be excluded.

The possibility that one or two $G$ residues could be present at the 5 ' terminus was not resolved by our 5'-RACE results. We reasoned that the presence of two $G$ residues initiating the genome might represent an artifact of reverse-transcription, which frequently will add an extra $\mathrm{C}$ residue complementary to the position of the cap structure (19). To test this, additional experiments employing clone constructs incorporating either one or two terminal $G$ residues confirmed reduced infectivity and virus accumulation in plants inoculated with a variant having two $G$ residues rather than one at the $5^{\prime}$ terminus (not shown). Combined, these results indicate that the $5^{\prime}$ terminus of MRFV-US begins with the sequence $5^{\prime}$ GUCC $-3^{\prime}$ and is likely capped, as would be expected for an $\alpha$-virus-like plant virus.

Relative to the MRFV-US nucleotide sequence, a single base insertion (following nucleotide C-1935) followed by a single base deletion (nucleotide C-1968) results in the sequence SRRRRRAR RAA being encoded in the large polyprotein in the reported sequence of the Costa Rican isolate. By contrast, PVAVASPAVQP is encoded in this same position in pMRFV-US and other MRFV clones obtained herein (not shown) in MRFV sequence obtained by RNAseq of field grown maize (L. R. Stewart, unpublished), and in the closely related SwMV (1). Accounting for these singlenucleotide indels would result in MRFV-CR encoding the sequence PVAVVAPAVQP, possessing two conservative substitutions relative to the amino acids encoded by MRFV-US. Therefore, we propose that these indels may represent a cloning or sequencing artifact in the original MRFV-CR sequence. Additional small changes were observed between the two sequences, as would be expected for isolates obtained from widely separated geographic regions.

Members of the Tymoviridae family express large polyproteins as precursors that become cleaved by a viral proteinase, and the products of the cleavage are presumed to become active components of the virus replication complex (15). Experiments by Jakubiec et al. (23) have expanded our understanding of the location and role of the cleavage sites in the TYMV polyprotein, sites also present in predicted marafiviral polyproteins and demonstrated to

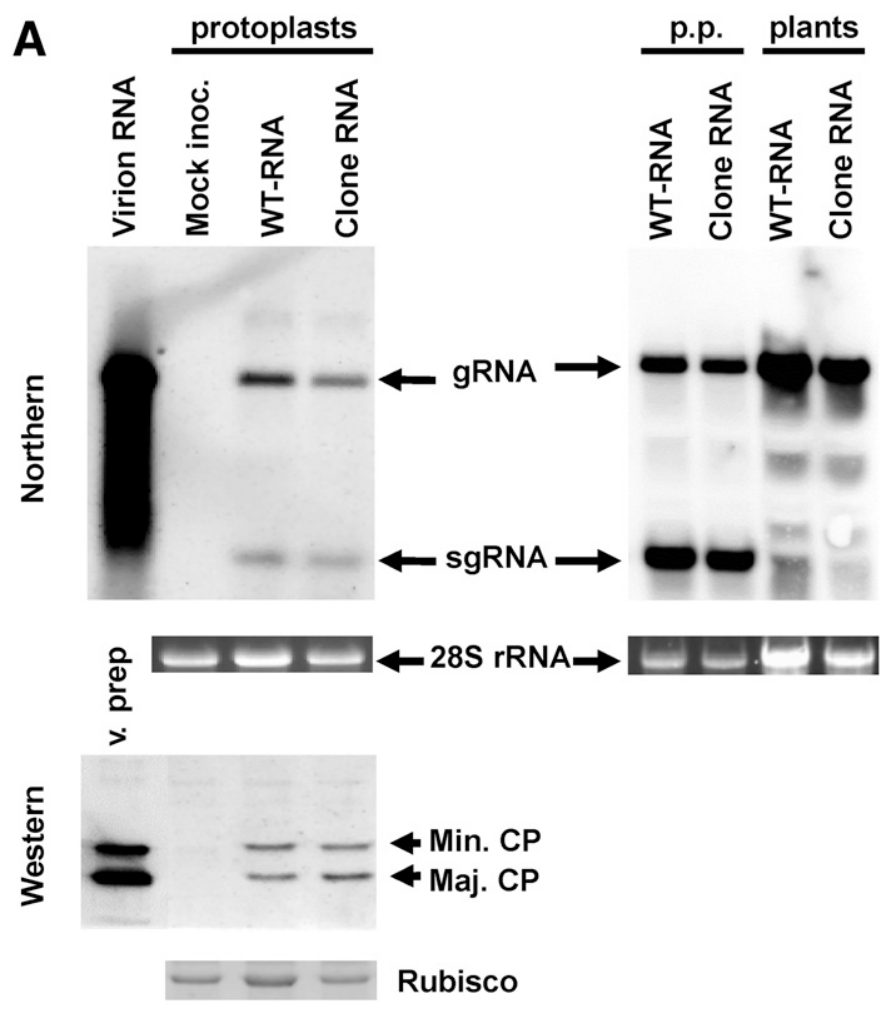

B

GSyV-1

CSDaV

OBDV

GRVFV

BELV

BlvS

GAMaV

MRFV

SwMV

OLV-3

PnMV

TYMV CAGGGUGAAUUGCUUCAA AGCUUCUCAAUGAUGCAA
CAAGGUGAAUUGCUUCA CACUUUC-AAGUACCAUUC
CAGGGUGAAUUGCUUCA ACGUUCC-ABUGCUCCAAUG
CAAGGUGAAUUGCUUCAU GCCUUUCAAUGUCAUCA
CAGGGUGAAUUGCUUCAGCUCUUUC-AACCUGAUCGC
CAGGGUGAAUUGCUUCAGUCUUUUC-AAUUUGUGCCU
CAGGGUGAAUUGCUUCAG CAUCUCC-AAUCUGUCC
CAGGGUGAAUUGCUUCAUCAGUUCC-AAUCGCUUCA
CAGGGUGAAUUGCUUCA CCAGUUCC-AAUCUCUCCA
CAAGGUCAAUUGCUUGCOUCUUUUC-AACAUUGAGCA
CAGGGUGAAUUGCUUCAGAACUUCC-AAGAAUCUAAC
GAGUCUGAAUUGCUUCACUACGUCC-AAUAGCAAUCA

Fig. 3. A, Differential accumulation of subgenomic RNA (sgRNA) in maize protoplasts versus plants inoculated with Maize rayado fino virus U.S. isolate (MRFV-US). In the left panel, extracts were prepared from maize protoplasts at $24 \mathrm{~h}$ postinoculation with wild-type or cloned MRFV-US RNA. In the right panel, extracts were prepared from protoplasts (pp) at $40 \mathrm{~h}$ postinoculation and from plants at 28 days postinoculation. Genomic RNA (gRNA) and sgRNA were detected by hybridization with a $3^{\prime}$-end probe (Northern blot), and major (Maj. CP) and minor (Min. CP) viral capsid protein were detected using antiMRFV antiserum (Western blot). Purified MRFV (v.prep) or RNA (virion RNA) were included as size standards. Ethidium-bromide-stained 28S rRNA and Coomassie-stained Rubisco served as well-loading controls. B, Alignment of the 'marafibox' (boxed sequence) and proposed transcriptional start site of sgRNA synthesis (bent arrow) for MRFV. Experimentally confirmed transcriptional start sites for Oat blue dwarf virus (OBDV) (10) and Turnip yellow mosaic virus (TYMV) (39), a representative tymovirus, are underlined. GSyV-1 = Grapevine Syrah virus-1, $\mathrm{CSDaV}=$ Citrus sudden death-associated virus, GRVFV = Grapevine rupestris vein feathering virus, $\mathrm{BELV}=$ Bermuda grass etched-line virus, BIVS = Blackberry virus $S, \mathrm{GAMaV}=$ Grapevine asteroid mosaic-associated virus, SwMV = Switchgrass mosaic virus, OLV-3 = Olive latent virus-3, and PnMV = Poinsettia mosaic virus . 
participate in the processing of one of the capsid proteins of OBDV (10). Chenon et al. (5) recently demonstrated that the TYMV proteinase is a deubiquitinating enzyme as well as a processing enzyme for its polyprotein (23), a feature further found to be shared with animal viruses in the order Nidovirales (34) and likely in all members of the plant virus family Tymoviridae. Based on an alignment of predicted marafivirus and tymovirus polyprotein sequences, a potentially novel cleavage site for this protease was revealed by the present investigation. The conserved LXG(G/A) $\downarrow$ cleavage site previously identified in OBDV capsid protein processing (10), and which is similar to cleavage sites in tymoviral nonstructural protein processing (23), is present in the aminoterminus of several known and proposed marafiviruses (Fig. 4). Moreover, based on this alignment, the location of the predicted cleavage site coincides with the relative position of the amino terminus in sequenced tymoviruses, as represented by TYMV in Figure 4. We propose that this feature reflects the divergent biology of the marafi- and tymoviruses, even as they share a common ancestral lineage (15). For example, the amino terminal extension present in the polyproteins of marafiviruses relative to those of tymoviruses may be involved in leafhopper transmission of marafiviruses, whereas the absence of the extension might be necessary for optimal replication in plants. The role of the amino terminal extension and its proposed cleavage during marafivirus replication awaits further studies.

Marafiviruses are unique among positive-strand RNA viruses for their potential usefulness in the study of virus-vector relationships, phloem limitation, and the ability to infect both plant and insect hosts. Moreover, their close relationship with the tymoviruses, for which several infectious clones exist $(35,40,41)$, should facilitate inquiries into the divergent biology of these two virus genera. The existence of an infectious clone for MRFV combined with recently developed

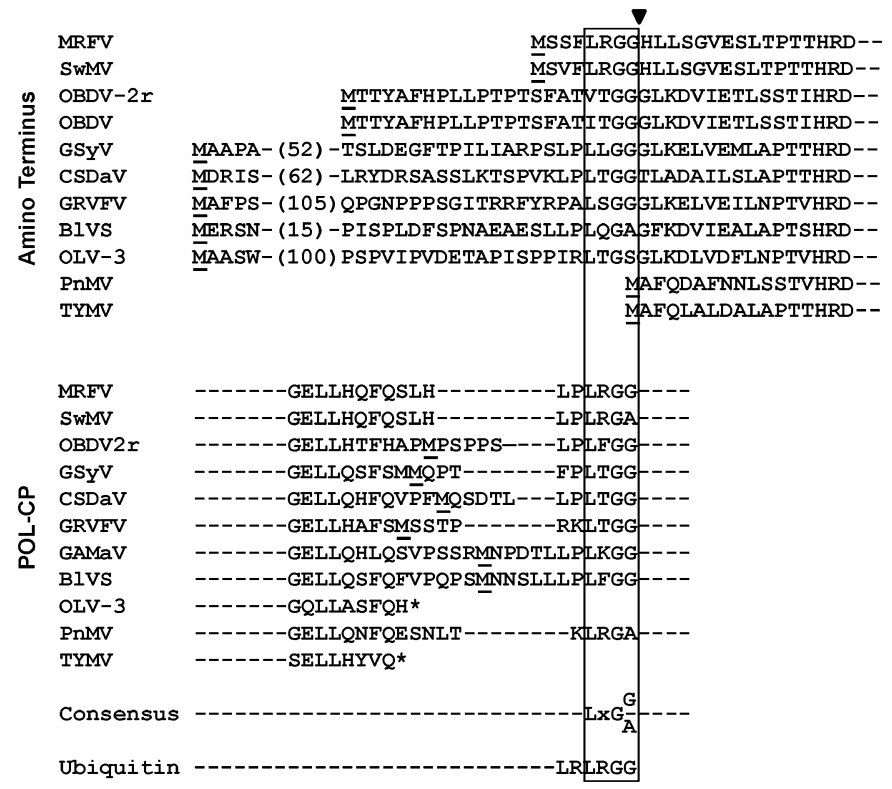

Fig. 4. Potential processing of the amino termini of the marafiviral large polyproteins. Putative cleavage sites (LXG[G/A/S $]$ ) in the amino termini are shown along with those at the polymerase coat protein (pol-CP) junction (black triangle); all sequences are aligned with reference to the demonstrated Oat blue dwarf virus (OBDV) Pol-CP and ubiquitin cleavage sites (10). Putative initiator methionines are underlined. Turnip yellow mosaic virus (TYMV) is included as a representative tymovirus. OBDV (NC_001793) and OBDV-2r (GU396990) sequences differ in one amino acid within the putative amino terminal cleavage site and, thus, both are included in the alignment. $\mathrm{MRFV}=$ Maize rayado fino virus, $\mathrm{SwMV}=$ Switchgrass mosaic virus, GSyV-1 = Grapevine Syrah virus-1, CSDaV = Citrus sudden death-associated virus, GRVFV $=$ Grapevine rupestris vein feathering virus, BIVS = Blackberry virus $S, \mathrm{OLV}-3=$ Olive latent virus-3, and PnMV = Poinsettia mosaic virus. approaches for marafivirus infection of plants and protoplasts will now enable further investigations into these fundamental issues.

\section{ACKNOWLEDGMENTS}

Funding for this work was provided by USDA-ARS CRIS project number 5442-22000-048-00D. Mention of trade names or commercial products in this publication is solely for the purpose of providing specific information and does not imply recommendation or endorsement by the U.S. Department of Agriculture. USDA is an equal opportunity provider and employer.

\section{LITERATURE CITED}

1. Agindotan, B. O., Gray, M. E., Hammond, R. W., and Bradley, C. A. 2012. Complete genome sequence of Switchgrass mosaic virus, a member of a proposed new species in the genus Marafivirus. Arch. Virol. 157: 1825-1830.

2. Banttari, E. E., and Zeyen, R. J. 1970. Transmission of oat blue dwarf virus by the aster leafhopper following natural acquisition or inoculation. Phytopathology 60:399-402.

3. Bradfute, O. E., Nault, L. R., Gordon, D. T., Robertson, D. C., Toler, R. W., and Boothroyd, C. W. 1980. Identification of maize rayado fino virus in the United States. Plant Dis. 64:50-53.

4. Carloni, E., Carpane, P., Paradell, S., Laguna, I., and Giménez Pecci, M. P. 2013. Presence of Dalbulus maidis (Hemiptera: Cicadellidae) and of Spiroplasma kunkelii in the temperate region of Argentina. J. Econ. Entomol. 106:1574-1581.

5. Chenon, M., Camborde, L., Cheminant, S., and Jupin, I. 2012. A viral deubiquitylating enzyme targets viral RNA-dependent RNA polymerase and affects viral infectivity. EMBO J. 31:741-753.

6. Clark, M. F., and Adams, A. N. 1977. Characteristics of the microplate method of enzyme-linked immunosorbent assay for the detection of plant viruses. J. Gen. Virol. 34:475-483.

7. Dreher, T. W. 2004. Turnip yellow mosaic virus: Transfer RNA mimicry, chloroplasts and a C-rich genome. Mol. Plant Pathol. 5:367-375.

8. Edwards, M. C., and Weiland, J. J. 2010. First infectious clone of the propagatively transmitted Oat blue dwarf virus. Arch. Virol. 155:463-470.

9. Edwards, M. C., and Weiland, J. J. 2011. Presence of a polyA tail at the 3'-end of Maize rayado fino virus RNA. Arch. Virol. 156:331-334.

10. Edwards, M. C., and Weiland, J. J. 2014. Coat protein expression strategy of Oat blue dwarf virus. Virology 450-451:290-296.

11. Edwards, M. C., Zhang, Z., and Weiland, J. J. 1997. Oat blue dwarf marafivirus resembles the tymoviruses in sequence, genome organization, and expression strategy. Virology 232:217-229.

12. Espinoza, A. M., Ramirez, P., and Leon, P. 1988. Cell-free translation of maize rayado fino virus genomic RNA. J. Gen. Virol. 69:757-762.

13. Falk, B. W., and Tsai, J. H. 1986. The two capsid proteins of maize rayado fino virus contain common peptide sequences. Intervirology 25:111-116.

14. Gámez, R. 1983. The ecology of maize rayado fino virus in the American tropics. Pages 267-275 in: Plant Virus Epidemiology. R. Plumb and J. Thresh, eds. Blackwell Scientific Publications, Oxford.

15. Gibbs, A. J., Haenni, A.-L., Jupin, I., Martelli, G. P., Edwards, M. C., Koenig, R., Hammond, R. W., Sabanadzovic, S., and Dreher, T. W. 2011. Family Tymoviridae. Pages 944-952 in: Virus Taxonomy, Ninth Rep. Int. Committee on the Taxonomy of Viruses. A. King, M. Adams, E. Carstens, and E. Lefkowitz, eds. Elsevier, Oxford.

16. Gordon, D. T., Nault, L. R., Gordon, N. H., and Heady, S. E. 1985. Serological detection of corn stunt spiroplasma and maize rayado fino virus in field-collected Dalbulus spp. from Mexico. Plant Dis. 69:108-111.

17. Hammond, R. W., and Hammond, J. 2010. Maize rayado fino virus capsid proteins assemble into virus-like particles in Escherichia coli. Virus Res. 147:208-215.

18. Hammond, R. W., and Ramirez, P. 2001. Molecular characterization of the genome of Maize rayado fino virus, the type member of the genus Marafivirus. Virology 282:338-347.

19. Hirzmann, J., Luo, D., Hahnen, J., and Hobom, G. 1993. Determination of messenger RNA 5 -ends by reverse transcription of the cap structure. Nucleic Acids Res. 21:3597-3598.

20. Hogenhout, S. A., Ammar, D., Whitfield, A. E., and Redinbaugh, M. G. 2008. Insect vector interactions with persistently transmitted viruses. Annu. Rev. Phytopathol. 46:327-359.

21. Hruska, A., Gladstone, S., and Obando, R. 1996. Epidemic roller coaster: Maize stunt disease in Nicaragua. Am. Entomol. 42:248-252.

22. Izadpanah, K., Zhang, Y. P., Daubert, S., Masumi, M., and Rowhani, A. 2002. Sequence of the coat protein gene of Bermuda grass etched-line virus, and of the adjacent 'marafibox' motif. Virus Genes 24:131-134. 
23. Jakubiec, A., Drugeon, G., Camborde, L., and Jupin, I. 2007. Proteolytic processing of turnip yellow mosaic virus replication proteins and functional impact on infectivity. J. Virol. 81:11402-11412.

24. Kitajima, E. W., and Gámez, R. 1977. Histological observations on maize leaf tissues infected with rayado fino virus. Turrialba 27:71-74.

25. Kitajima, E. W., and Gámez, R. 1983. Electron microscopy of maize rayado fino virus in the internal organs of its leafhopper vector. Intervirology 19:129-134.

26. Kitajima, E. W., Yano, T., and Costa, A. S. 1976. Purification and intracellular localization of isometric virus-like particles associated with Brazilian corn streak virus infection. Cienc. Cult. 28:427-430.

27. Larkin, M. A., Blackshields, G., Brown, N. P., Chenna, R., McGettigan, P. A., McWilliam, H., Valentin, F., Wallace, I. M., Wilm, A., Lopez, R., Thompson, J. D., Gibson, T. J., and Higgins, D. G. 2007. Clustal W and Clustal X version 2.0. Bioinformatics 23:2947-2948.

28. Leon, P., and Gamez, R. 1981. Some physicochemical properties of maize rayado fino virus. J. Gen. Virol. 56:67-75.

29. Lockhart, B. E. L., Khaless, N., Lennon, A. M., and El Maatauoi, M. 1985. Properties of Bermuda grass etched-line virus, a new leafhopper transmitted virus related to maize rayado fino and oat blue dwarf viruses. Phytopathology 75:1258-1262.

30. Louie, R. 1995. Vascular puncture of maize kernels for the mechanical transmission of maize white line mosaic virus and other viruses of maize. Phytopathology 85:139-143.

31. Madriz-Ordeñana, K. 1999. Molecular studies of the defence responses of maize (Zea mays L.) in interaction with maize rayado fino marafivirus (MRFV). Ph.D. thesis, Department of Plant Biology, The Royal Veterinary and Agricultural University, Copenhagen, Denmark.

32. Madriz-Ordeñana, K., Rojas-Montero, R., Lundsgaard, T., Ramírez, P., Thordal-Christensen, H., and Collinge, D. B. 2000. Mechanical transmission of maize rayado fino marafivirus (MRFV) to maize and barley by means of the vascular puncture technique. Plant Pathol. 49:302-307.

33. Matsuda, D., and Dreher, T. W. 2005. In vivo translation studies of plant viral RNAs using reporter genes. Online publication. Curr. Protocols Microbiol. Unit 16K.2.
34. Mielech, A. M., Chen, Y., Mesecar, A. D., and Baker, S. C. 2014. Nidovirus papain-like proteases: Multifunctional enzymes with protease, deubiquitinating and deISGylating activities. Virus Res. 194:184-190.

35. Min, B. E., Feldman, T. S., Ali, A., Wiley, G., Muthukumar, V., Roe, B. A., Roossinck, M., Melcher, U., Palmer, M. W., and Nelson, R. S. 2012. Molecular characterization, ecology, and epidemiology of a novel Tymovirus in Asclepias viridis from Oklahoma. Phytopathology 102: 166-176.

36. Nault, L. R., Gingery, R. E., and Gordon, D. T. 1980. Leafhopper transmission and host range of maize rayado fino virus. Phytopathology 70: 709-712.

37. Rivera, C., and Gámez, R. 1986. Multiplication of maize rayado fino virus in the leafhopper vector Dalbulus maidis. Intervirology 25:76-82.

38. Sambrook, J. F., and Russell, D. W. 2001. Molecular Cloning: A Laboratory Manual, 3rd ed. Vol. 1, 2, and 3. Cold Spring Harbor Laboratory Press, Plainsview, NY.

39. Schirawski, J., Voyatzakis, A., Zaccomer, B., Bernardi, F., and Haenni, A.-L. 2000. Identification and functional analysis of the turnip yellow mosaic tymovirus subgenomic promoter. J. Virol. 74:11073-11080.

40. Skotnicki, M. L., Ding, S. W., Mackenzie, A. M., and Gibbs, A. J. 1993. Infectious eggplant mosaic tymovirus and ononis yellow mosaic tymovirus from cloned cDNA. Arch. Virol. 131:47-60.

41. Weiland, J. J., and Dreher, T. W. 1989. Infectious TYMV RNA from cloned cDNA: Effects in vitro and in vivo of point substitutions in the initiation codons of two extensively overlapping ORFs. Nucleic Acids Res. 17:4675-4687.

42. Weiland, J. J., and Edwards, M. C. 1994. Evidence that the $\alpha$ a gene of barley stripe mosaic virus encodes determinants of pathogenicity to oat (Avena sativa). Virology 201:116-126.

43. Weiland, J. J., and Edwards, M. C. 2011. Linear-motion tattoo machine and prefabricated needle sets for the delivery of plant viruses by vascular puncture inoculation. Eur. J. Plant Pathol. 131:553-558.

44. Zambrano, J. L., Francis, D. M., and Redinbaugh, M. G. 2013. Identification of resistance to Maize rayado fino virus in maize inbred lines. Plant Dis. 97:1418-1423. 